\title{
THE INFLUENCE OF BIG DATA CONCEPT ON FUTURE TENDENCIES IN PAYMENT SYSTEMS
}

\begin{abstract}
The new wave of information and communication technology transformation relies on the concepts of the Internet of Things, Big Data and machine learning. These concepts will enable the connection and independent communication of a large number of devices, the processing of data that arises as a result of these processes and learning based on the refined information. Payment system is a sector that will experience major impacts by the coming changes. A large number of transactions create an information basis, whose analysis can provide precise inputs for business decision making. The subject of paper is the impact of managing a large amount of transactional data on key stakeholders in the payment process. The aim of the paper is to identify the key advantages and dangers that the Big Data concept will bring to the payment industry. The general conclusion is that the use of Big Data tools can facilitate the timely distribution of payment services and increase the security of transactions, but the price in the form of a loss of privacy is extremely high.
\end{abstract}

Keywords: Big Data, electronic payments, privacy, data misuse, mobile digital wallets;

University of Kragujevac, Faculty of Economics, Kragujevac, Serbia; ntomic@kg.ac.rs

** University of Kragujevac, Faculty of Economics, Kragujevac, Serbia; v.todorovic@kg.ac.rs 


\section{INTRODUCTION}

The key features of information and communication technologies (ICT) progress are the development of computer systems and the creation of telecommunication networks for data exchange. The changes have become continual process, so instead of Information revolution we can speak about Information evolution. The capacities for data processing, as well as the speed of data transmission via the network, are constantly increasing. Adequate collection, processing and use of data have become precondition for successful business activities. The volume of available data exponentially grows from year to year, making their management more complicated. The problem of modern business is not just collection of data, but also their classification according to the importance and observation of patterns that could be applied in the business processes.

A newdominant wave of ICT innovations has been intensified in recent years, which has changed relative importance of certain devices and information processes. Its basic pillars are Internet of Things, Big Data and Machine learning. These processes could enable connection and independent communication of large number of devices in homes and companies, without humans in direct control. New types of connections would make even larger amount of data, which would make their collection, processing and use more difficult. Devices will have the opportunity to learn, or to make conclusions based on previous experience and to adjust their behavior ${ }^{1}$. Hence, a new approach in managing large amount of data is needed.

The subject of paper is the impact of managing a large amount of transactional data on key stakeholders in the payment process. The aim of the paper is to identify the key advantages and dangers that the Big Data concept will bring to the payment industry.Previous researches on this topic are not abundant. Some authors have emphasized the importance of mobile digital wallets as payment applications of the future ${ }^{2}$. The others have analyzed the possibilities of interaction between cryptocurrencies and Big Data, focusing on two key aspects: increasing customers' security and predicting the movement of cryptocurrencies values $^{3}$. There have also been some skeptic beliefs that the application of the Big Data tools in the field of finance, as well as other areas, will bring less value than what investors expect ${ }^{4}$.

$1 \quad$ Song Il-Yeol, Zhu Yongjun(2017):"Big Data and Data Science: Opportunities and Challenges of iSchools", Journal of Data and Information Science, 3/2017, 1-18

2 Liu Jun, Kauffman Robert John, Ma Dan (2015):“Assessing the Opportunities and Challenges with Big Data in the Mobile Payments Ecosystem", Workshop on Internet and Big Data Finance 2015, Research Collection School Of Information Systems, Singapore

3 Hassani Hossein, Huang Xu, Silva Emmanuel (2018):"Big-Crypto: Big Data, Blockchain and Cryptocurrency", Big Data and Cognitive computing, 4/2018

4 RossJeanne, Beath Cynthia, QuaadgrasAnne (2013):“You May Not Need Big Data After All", Harvard business review, 10/2013 
In the first part of the paper, the Big Data concept and its key features will be analyzed. In the second part, the application of this concept in the case of transactional information will be considered. In the third part it will be possible to observe the dangers of Big Data analysis that arise from opposite interests of stakeholders in the payment process.

\section{THE NEED FOR ADVANCED DATA MANAGEMENT}

The progress of ICT technology enabled faster data collection, its storage, processing and use in decision making. In the last few years, companies are facing with different problem in data management. In every phase of business process, companies collect huge volumes of data, so that databases become overloaded. Today's data bases are measured in petabytes $\left(10^{3} \mathrm{~GB}\right)$ and exabytes $\left(10^{4}\right.$ GB), which makes their loading and storage extremely long lasting and expensive $^{5}$. Since the prices of storage space have fallen, many entities simply store all data they collect, rather than deleting them ${ }^{6}$. Therefore, it is difficult to process those data so that they provide consistent conclusions, because it is often a matter of incomparable data of a different nature and priority.

Big Data denotes collection, processing, analysis and management of data that are diverse and extensive, are created at a high speed and have different structures ${ }^{7}$. It means that there are huge volumeof information generated in a unit of time, while among them there is a high diversity in the terms of origin, priority and usability. The multiplication of information is encouraged by the increasingly pronounced networking of devices and objects in the human surrounding. IoT implies the highest form of integration of people with the devices and objects used both in business processes and also in everyday life. The Global Standard Initiative states that the IoT is a network of devices, machines, vehicles and objects that are connected through the communication networks such as the Internet, NFCs and RFIDs, equipped with microprocessors, sensors and appropriate software, which enables data collection and timely distribution ${ }^{8}$. On this occasion, an M2M type of connection is made, with both Ms representing machines or one $M$ representing man and the other one machine (also referred to as M2P connection - machine-to-person). The goal of establishing such a net-

$5 \quad$ Everts Sarah (2016):"Information Overload”, Distillations, 2/2016, 26-33

6 Mayer-Schönberger Viktor, Cukier Kenneth (2014):Big Data: A revolution that will transform how we live, work, and think, London: John Murray

Lukićjelena (2014):"The impact of information and communication technology on decision making process in the Big Data Era", Megatrend revija, 2/2014, 227

8 Global Standard Initiative for Internet of Things (2016) Harnessing the Internet of Things for global development, International Telecomunication Union, Geneva, Switzerland 
work is to create an automated business environment in which a „smart environment" will allow routine operations to be performed faster'.

It is necessary to process large amounts of generated data so that they serve in the decision-making process. Machine learning is a mathematical technique for creating an algorithm that, on the basis of a given sample of data, can learn to take the necessary actions without direct programming ${ }^{10}$. An example is algorithms that know to detect spam even though they are not directly programmed to filter the messages of a particular sender.

Contemporary databases contain large amount of useless data that not only occupy free space, but also make finding useful pieces difficult ${ }^{11}$. In such circumstances, sorting data before their processment requires significant resources, making data management more expensive. The Big Data tools are used in analysis of the structured, semi-structured and unstructured data from different resource, whereby their scope and required processing speed exceed abilities of standard analytical tools and methods ${ }^{12}$. An important feature of the concept is possibility for real-time data processing and providing the necessary information at the moment of action.

The databases that are suitable for managing Big Data tools are characterized by the following features, in the literature known as "5V”: volume, velocity, variability, veracity and value ${ }^{13}$. Some authors provide a more extensive description, and cite up to "17V” characteristics ${ }^{14}$. This means that volume is not the only characteristic of data suitable for processing with Big Data tools. High speed of data generation, changes in the dynamics of their generation, different formats and high value make one database suitable for Big Data tools. An example is an airplane, whose sensors generate a large amount of data on the external and internal state of the aircraft by varying dynamics. Although it is not a large database, because the data for several hours of flight take only several GB of storage space, it can be considered Big Data example because of the speed of generation and variety of information.

$9 \quad$ TomićNenad, Todorović Violeta (2016) Possibilities for Application of Electronic Payment Systems in Retail,in: Sinteza 2016 - International Scientific Conference on ICT and E-Business Related Research, Belgrade, Singidunum University, Serbia p. 461

10 Bishop Christopher (2006), Pattern Recognition and Machine Learning, Springer

$11 \quad$ Waldherr Annie, Maier Daniel, Miltner Peter, Günther Enrico (2016):“Big Data, Big Noise: The Challenge of Finding Issue Networks on the Web", Social Science Computer Review, 4/2016, 427

12 AlamJafar Raza, SajidAsma, TalibRamzan,NiazMuneeb (2014):“A Review on the Role of Big Data in Business", International Journal of Computer Science and Mobile Computing, 4/2014, 446

13 Ishwarappa Kalbandi, Anuradha J. (2015): “A Brief Introduction on Big Data 5 vs Characteristics and Hadoop Technology", Procedia Computer Science, 48/2015, 320-321

14 ArockiaPanimalar, Varnekha Shree, Veneshia Kathrine, (2017):“The 17 V's Of Big Data”, International Research Journal of Engineering and Technology, 9/2017, 329-333 
It is shown that companies which have prepared strategy for big data management have achieved a competitive advantage and that they dominate in their industries (for example, Amazon and Uber). These companies have grasped the importance of data analysis and its benefit in making interactions with customers. An additional impulse to Big Data strategies was given by social networks and electronic payment systems (EPS). Both types of applications provide the great amount of data about consumers, which could be used for commercial purposes. One should bear in mind that the use of personal information is a special issue of legal nature.

In order to benefit from managing large data sets, companies have to learn ${ }^{15}$ :

- To use Big Data analysis techniques in order to create value and to achieve competitive advantage;

- To use new technologies and to get the maximum from existing technology assets;

- To enable organizational change with adopting new technologies;

- To provide faster and superior results with accepting growing rates of changes which take place on the global market.

The Big Data concept is not strictly connected to the commercial activities. The great use is expected in sports, traffic, meteorology and management of government data ${ }^{16}$.Particularly significant benefits are expected from the application of this concept in healthcare. The first area of Big Data application for medical purposes is the processing of so-called clinical data. It is data on the causes, symptoms and development of the disease, collected by hospitals and clinics $^{17}$. Another area of application is public health. Advanced ICTs have enabled the development of wearable systems for monitoring human vital activities and health condition. The third area of application involves managing the mass of data obtained in medical experiments. In addition, Big Data could certainly be widely used in the medical literature for systematization of general and specific knowledge gained from previously listed data sources ${ }^{18}$.

$15 \quad$ Minelli Michael, Chambers Michele, Dhiraj Ambiga (2013):Big data, big analytics, New Jersey, NJ: John Wiley \& Sons

16 PavlovićRastko, Dejanović Ratko (2014):“Big Data i poslovna strategija”, Infoteh-Jahorina, Bosna i Hercegovina, 13, 754-758

17 Tsumoto Shusaku, Hirano Shoji, Iwata Haruko (2013). Mining nursing care plan from data extracted from hospital information system. Paper presented at the 2013 IEEE/ACM International Conference on Advances in Social Networks Analysis and Mining, Niagara Falls, ON, Canada , Big Data in Health Care: Applications and Challenges

18 Hong Liang, Luo Mengqi, Wang Ruixie, Lu Peixin, Lu Wei, Lu Long (2018) Big Data in Health Care: Applications and Challenges, Data nad Information Management 


\section{BENEFITS OF APPLYING THE BIG DATA CONCEPT IN ELECTRONIC PAYMENTS}

In order to enable the implementation of Big Data concept in electronic payments, it is necessary to collect as much information about payer as possible. Smart mobile phones are the ideal aggregator of necessary information. Based on the combination of transactional information, preference for specific products or services and location, the Big Data tools can provide timely distribution of payment services and increase the security of payments.

The first operative solutions of EPS were used solely for electronic trade. Smart mobile phones and near field communications (NFC) have created infrastructure for implementation of EPS in retail. Mobile phone payments in China for the first time exceeded payments initiated through personal computers in 2015 , and the year after they even made two thirds of all electronic payments ${ }^{19}$. At the same time, payments initiated through personal computers still dominate in USA and EU, but mobile payments show high rates of growth ${ }^{20}$.Trend Force's projection shows that despite the slowdown in the annual growth rate of mobile payments value, it will remain two-digit, while the total value of mobile payments in 2019 will exceed thousand billion dollars (see Diagram 1 for a full forecast).

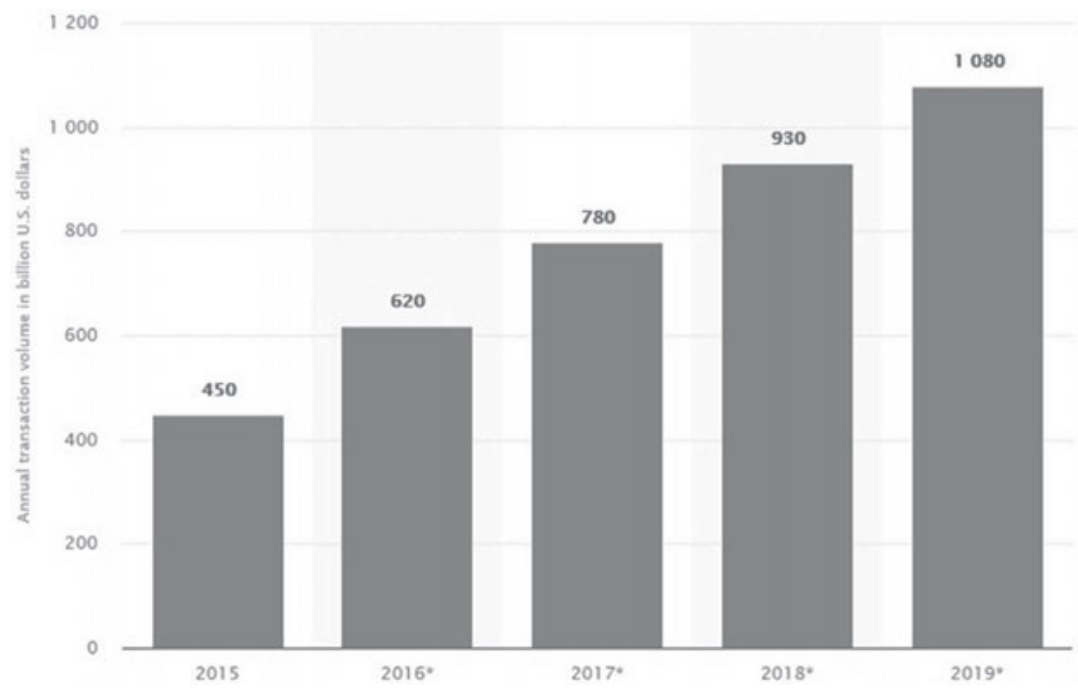

Source: https://press.trendforce.com/press/20160201-2298.html (retrieved February 2nd 2019)

Diagram 1: Total revenue of global mobile payment market from 2015 to 2019

Evans Michelle (2017):“Three Payment Trends That Will Change How We Pay in 2018”,
Forbes, October 27
https://ecommercenews.eu/key-figures-mobile-commerce-europe-revealed/ (retrieved
February 2nd 2019) Megatrend revija Megatrend Review 
With the emergence of new operating systems, technical base of mobile phones strengthens, because faster processors and increased RAM respond faster to consumers' requests ${ }^{21}$. New phones are getting closer to personal computers by the ability to process data and execute given commands. Along with the development of mobile applications for the large number of EPS, smart phones have become the base for the development of mobile digital wallets ${ }^{22}$.These currently represent the most innovative class of EPS. They contain a database of preferred payment methods for the phone owner - debit and credit card numbers, PIN numbers for each of the cards, card expiration dates, as well as personal information such as the address to which the card is registered, delivery addresses and others $^{23}$. At appropriate moment, the mobile digital wallet makes the stored data available and practically automates the process that the user would normally do manually. The ability to match payment cards with loyalty cards, gift cards or cards issued by a retailer is another advantage. This allows customer to directly make a discount when making payments, collect points for special prizes or use previously approved bonuses.

Two motives for an increase in number of companies that enter into the mobile digital wallets market are transaction processing fees and access to the source of information. Although processing fees may seem as a key motive, information control becomes more and more important. Banks have given up the ability to commercialize the data in their possession by committing themselves to clients' privacyprotection. EPS have also stated in user agreements to protect the personal data. However, the circumstances under which the EPS operate are fundamentally different from traditional banking operations. Customers are aware that while browsing the Internet, a large number of websites follow their behaviour, especially if it discloses their preferences to certain products and services. In such situations, customers' privacy preferences only relate to the prevention of data theft, not the secrecy of transactions. It is therefore not surprising that EPS are less consistent then banks in preservingcustomers' privacy.

EPS payments represent only a small portion of all customers' transactions. Even assuming that the customer does not use cash, there is a variety of payment instruments to choose from. Not even banks can create a complete picture of their clients' payments, as they can use debit and credit cards of different issuing banks, gift cards or merchants' loyalty card. The data that intermediaries can obtain are a sample, which does not necessarily reflect all of customers' habits. That shows the full potential of mobile digital wallets, because they are conceived as an application that combines all payment instruments that the customer has

$21 \quad$ Phillips Casey (2014):"How Smartphones Revolutionized Society in Less than a Decade”, GovTech, November $20^{\text {th }}$

22 Anderton Kevin (2016):“Mobile Payment And The Future Of Money”, Forbes, April 29

23 Kemp Richard (2013):"Mobile payments: Current and emerging regulatory and contracting issues", Computer Law and Security Review, 29/2013, 175-179 
at disposal. Within single application, there are payments made for e-commerce and retail purchases as well as usage of loyalty cards and collection of discounts. In developed economies, where the cash-use rate is at a low level, the mobile digital wallet provider can reach almost all of customer's payment data.

Banks play the role of executor in payment transactions. Until now, banks and other payment institutions did not have the means to actively participate in the creation of transactions. Thanks to the integration of mobile digital wallets with other mobile applications, banks and payment institutions can directly influence customers' decisions. Information coming from GPS modules, social networks and Internet browsers enable payment institutions to get to know the user more closely.

For example, a customer searches for winter sports equipment through a mobile browser. As the GPS is activated on his mobile phone, the customer receives a notification when the next time he is in vicinity of the winter sports equipment store. His bank offers him a loan for the purchase of sports equipment at a low interest rate. Here, the bank takes the initiative for direct distribution of its product (short-term loan) and influences the decision of its client, instead of just executing transactions ${ }^{24}$. Of course, the final decision depends solely on the customer's attitude, but it can be considered that the lack of financial resources often delay or stop the purchase of this type of product. In the case that he decides to accept the offer, the user will buy goods that otherwise he would not be able to afford, and the bank will place the product for which there was no demand. Timely distribution of payment services generates value for customers, payment institutions (banks, ESP) and merchants.

Another key advantage is the increase in security by reducing the possibility of fraud by third parties. With different analysis techniques, it is possible to segment the transaction data into the components, each of which is compared with historical data and patterns. The aim is to identify the illogicality in the data indicating possible misuse. Thanks to these procedures, which are carried out with the help of adequate software solutions for the collection and processing of huge volumes of data, it is possible to stop misuses while they are still in progress. The risk of identity theft is significantly reduced in this way, because malicious users are stopped at a later stage of the transaction. Therefore, the entire Big Data transaction security strategy requires data management and real-time operation.

Largest Chinese auction website Alibaba has been successfully using a Big Data software solution to prevent abuse while shopping. The software performs a five-layer analysis of purchases in order to prevent misuse of customers' accounts. The first layer is the account check. Based on historical data and facts about buyer and seller, the trustworthiness of transaction is checked. It is necessary to determine whether there is a risk that the buyer's or seller's accounts have been compromised or have previously been involved in suspicious transactions.

24 http://www.paymenteye.com/2016/01/20/big-data-and-mobile-payments-the-game-changer (retrieved February 2nd 2019) 
The second layer is the device check. The aim is to determine whether the used device is the one customer usually uses and whether it is connected through the usual IP address. If the answer is negative, there is a high possibility that it is a misuse and the purchase may be stopped, or additional verification required. The third layer is the activity check. The authenticity of the purchase is checked within this step. It is necessary to determine whether the activity is consistent with the previous behavior of the buyer, whether he bought similar goods from similar sellers. If its behavior is atypical, it may be misuse. The fourth layer is a risk assessment strategy. Within this step, a decision on purchase is made either automated based on the algorithm, or it is sent to manual decision. Algorithms make clearly positive and clearly negative decisions. All uncertainties require additional checks that may take a while. On the one hand, Alipay wants payments to be quick and comfortable, but on the other it does not want to allow misuses. The fifth layer is a manual analysis, when needed ${ }^{25}$.

All parties benefit from increased security. Customers avoid locking accounts and losing funds. Merchants avoid fraudulent purchases for which they will have to refund assets, with the loss of a product or service. Payment institutions avoid reclamations and work stoppages.

\section{POSSIBLE MISUSES OF PERSONAL DATA}

Previously mentioned advantages bring benefits to all stakeholders in the electronic payment cycle. However, certain activities based on the application of the Big Data tools can produce conflict of interests of different participants. As a rule, in these situations the customer is on one side and the payment institution is on the other. The reason for such segmentation is that payment institutions, using customer's personal data, can act against his best interests. Merchants can be found on both sides, that is, they can be threatened by the payment institution's operation, or use its specific position.

Practically all negative tendencies that can be associated with the Big Data concept originate from the loss of user's privacy. Entrusting a large amount of data to a particular entity consequently leads to an attempt of misuse by the entity itself. Some forms of personal data misuses may seem benign, while the others are clear form of attack on the basic human rights.

Targeted sales represent the first group of misuses ${ }^{26}$. Previously mentioned example of purchasing sports equipment seems useful, however, it can only be

25 Cheng Jidong et al. (2015):“Big data based fraud risk management at Alibaba", The journal of financial and data science, 1/2015, 1-10

26 Anshari Muhammad et al. (2019):“Customer relationship management and big data enabled: Personalization \& customization of services", Applied Computing and Informatics, 2/2019, 94-101

Vol. 17, № 3, 2020: 115-130 
one in a series of offers that customers receive daily. In order to stimulate its services, payment institution can send offers for all forms of products and services customer has searched. This would cause customer's discomfort and the increase in unwanted purchases, due to the loss of autonomy in decision making. The situation would deteriorate further if the payment institution shared the data with merchants, who would then be able to send their own offers on a daily basis. A customer can find himself in a situation that he cannot evaluate the products in the right way, because of the huge offer of identical or very similar alternatives. These issues already exist on e-mail accounts, where a large amount of unwanted content arrives every day. In the future, digital wallets or map applications can be used to distribute commercial offers. It would be much more difficult for customer to avoid these contents, which increases the sense of discomfort.

The situation is even more worrying if one takes into account that in the future, the aggregation of financial data with data from social networks and mass messaging services could be possible. A payment institution could classify customers according to a psychological profile, as social networks classify according to the demographic profile. By identifying customers who are prone to suggestive spending, a payment institution can fully personalize offers and recommend targeted sales to appropriate merchants. The next step is sending suggestive ads to collectors, compulsive shoppers, or sending electronic gambling offers to customers found to be prone to gambling. The unethical nature of this practice is not in question, but in addition, it is necessary to bear in mind the possible extremely negative social effects.

Another significant possibility Big Data bring is a dynamic pricing policy. It is a very sensitive form of sales policy, in which the merchant constantly adjusts the level of prices for certain customers. Big Data would enable that real-time pricing policy, based on individual customer data ${ }^{27}$. In other words, by analyzing the affinity of each customer, an individual price would be formed, which should respond to his unique willingness to buy a particular product or service. The first disadvantage is that a dynamic pricing policy is applicable to a small number of products, usually luxurious ones, for which demand is less elastic. Greater applicability would be possible in the service sector, especially IT services. Another, much more significant disadvantage is that dynamic pricing policy is highly discriminatory. Without any economic justification, a higher price is charged to certain groups of customers, just because it is noticed that they spend more on similar products. This kind of capabilities qualifies Big Data as a concept that can especially harm individual customers by exposing their privacy entirely to business entities.

Another group of potential problems are much more obvious. By using the Big Data tool, the entity that has the appropriate data available can easily moni-

Le Thi Mai, Liaw Shu-Yi (2017):"Effects of Pros and Cons of Applying Big Data Analytics to Consumers' Responses in an E-Commerce Context”, Sustainability, 5/2017, 1-19 
tor each individual customer. Suppose that such an entity could be the state, which in different ways can exert pressure on companies that have disposable data to provide them. Similar cases have already been recorded, paradoxically, in Western countries. Under the excuse of the fight against terrorism, the states have taken over large amounts of data from telecommunications companies and Internet browsers ${ }^{28}$. A dictatorial authority could integrate customer's payment account with data from internet searches, communication on social networks and his movement tracks, to conclude that he represents a threat to national security. This conclusion does not necessarily have to be malicious. It has already been emphasized that Big Data tools process data from different structures that are not necessarily always reliable. Therefore, an individual's behaviour can accidently be interpreted as dangerous. Consciously blocking an individual due to anti-state behaviour opens a completely different problem of subjective assessments of undesirable behaviour and thus creates a vast space for abuses. By blocking the source of funds for one or more days, the state sends a clear message to the disloyal individual and all others who may act contrary to the interests of the authorities ${ }^{29}$.

By analyzing these situations, it becomes clear that the positive and negative aspects of Big Data tool application must be viewed from the perspective of the end users. Having in mind the problems that can arise, the availability and use of personal data should be carefully legally regulated. In doing so, regulation must be a continuous process that is constantly being re-examined, as the informational evolution is constant. Categories that have been defined and regulated are now changed under the influence of new devices and communication channels, which provide new ways to overcome old legal frameworks.

\section{CONCLUSION}

Although it seemed as a distant future only a few years ago, the new IT reality has already begun. Its three pillars, the Internet of Things, Machine Learning and Big Data are used in basic forms in a wide variety of activities. All three concepts are still far from taking a dominant role and becoming a commercial standard. One should keepin mind that it took over three decadesto transform computers in machines suitablein terms of price, dimensions and capabilities for individual customers and small firms. It can be expected that all three concepts will reach their full maturity and commercial application much faster. There are

28 Chen Hsinchun, Chiang Roger, Storey Veda (2012):"Business intelligence and analytics: From big data to big impact", MIS Quarterly, 4/2012, 1171-1172

29 TomićNenad, Todorović Violeta (2018): "Challenges of transition to cashless society", in: Babić Verica (ed.) Contemporary issues in Economics, business and management - EBM 2018 [proceedings of the international scientific conference], Kragujevac: Faculty of Economics, 317 
numbers of potential advantages associated with them, but also certain shortcomings and dangers of their unregulated use.

Mobile digital wallets in this moment represent the most suitable infrastructure for data aggregation. Owners of these wallets can distribute collected data to interested parties. Merchants and payment institutions then have the opportunity to directly offer their own products, which can be done both jointly and individually. The advantage of this distribution channel relative to targeted ads boosting on social network is that companies are offering the product to customers who are interested. Social networks allow company to make an offer to the targeted demographic group that does not need to be interested.

Another significant advantage is the ability to use large data set analysis in security purposes. Social networks, as Facebook does, prevent users from sending friend requests to people without visible connections, like mutual friends, common education, workplaces, or years of age. Information filters in payment systems must be more precise, and the comparison of historical data and those that emerge in real time plays a key role. If the Big Data software is able to use the algorithm to identify payment from a stolen account, the decennial problem of proper authentication of electronic payments can be overcome.

Nevertheless, the question of price of these benefits arises. In order to utilize its full potential, it is necessary to use as large data set as possible. This means that individual users will be confronted with an ever-increasing loss of privacy. The worst possible option is that users agree to share all requested information. Such an outcome is not entirely impossible, given the behavior of a large number of users on social networks. To expect that the companies with which the data are shared will be careful in using them is extremely naive. The possible problems mentioned in the third part of the paper show that the interests and the motives of stakeholders in this case are opposed.

The situation is even more worrisome given the position of the state. Instead of protecting its citizens and suppressing the violent behavior of large corporations, the state may require taking over all data for its own needs. This scenario would not be new and it would open another question. Once the user becomes part of the system in which every communication, search and purchase is monitored, will he ever be able come out? A possible solution is to formulate a flexible regulation of data collection and use, which will transparently monitor data management in large corporations. Such regulation should not be made solely by the state, due to its own interest in this field, but it should be necessary to include representatives of the association of consumers with appropriate knowledge. The question for further research is what would be effect on the overall problem if the withdrawal of cash occurs in the future. 


\section{Literature:}

- Alam Jafar Raza, Sajid Asma, Talib Ramzan, Niaz Muneeb(2014):"A Review on the Role of Big Data in Business", International Journal of Computer Science and Mobile Computing, 4/2014, 446-453

- Anderton Kevin (2016):“Mobile Payment And The Future Of Money”, Forbes, April $29^{\text {th }}$

- Anshari Muhammad, Almunawar Mahammad Nabil, Lim Syamimi Ariff, AlMudimigh Abdullah (2019):"Customer relationship management and big data enabled: Personalization \& customization of services", Applied Computing and Informatics, 2/2019, 94-101

- Arockia Panimalar, Varnekha Shree, Veneshia Kathrine, (2017):“The 17 V’s Of Big Data”, International Research Journal of Engineering and Technology, 9/2017, 329-333

- (2006), Pattern Recognition and Machine Learning, Springer

- Chen Hsinchun, Chiang Roger,Storey Veda (2012):"Business intelligence and analytics: From big data to big impact", MIS Quarterly, 4/2012, 1165-1188

- ChengJidong, TaoYe, Wang Haoran, ChenTao (2015):“Big data based fraud risk management at Alibaba", The journal of financial and data science, 1/2015, 1-10

- Evans Michelle (2017):“Three Payment Trends That Will Change How We Pay in 2018", Forbes, October $27^{\text {th }}$

- Everts Sarah (2016):“Information Overload”, Distillations, 2/2016, 26-33

- Global Standard Initiative for Internet of Things (2016) Harnessing the Internet of Things for global development, International Telecomunication Union, Geneva, Switzerland

- Hassani Hossein, Huang Xu, Silva Emmanuel (2018):"Big-Crypto: Big Data, Blockchain and Cryptocurrency", Big Data and Cognitive computing, 4/2018

- Hong Liang, Luo Mengqi, Wang Ruixie, Lu Peixin, Lu Wei, Lu Long (2018) Big Data in Health Care: Applications and Challenges, Data nad Information Management

- IshwarappaKalbandi, Anuradha J. (2015):"A Brief Introduction on Big Data 5Vs Characteristics and Hadoop Technology",Procedia Computer Science, 48/2014, 319-324.

- Kemp Richard (2013):"Mobile payments: Current and emerging regulatory and contracting issues", Computer Law and Security Review, 29/2013,175-179

- $\quad$ Le Thi Mai, Liaw Shu-Yi (2017):"Effects of Pros and Cons of Applying Big Data Analytics to Consumers' Responses in an E-Commerce Context”, Sustainability, 5/2017,1-19

- $\quad$ Liu Jun, Kauffman Robert John, Ma Dan (2015):“Assessing the Opportunities and Challenges with Big Data in the Mobile Payments Ecosystem”, Workshop on Internet and Big Data Finance 2015, Research Collection School Of Information Systems, Singapore 
- LukićJelena(2014):“The impact of information and communication technology on decision making process in the Big Data Era", Megatrend revija, 2/2014, 221233

- Mayer-Schönberger Viktor, Cukier Kenneth (2014):Big Data: A revolution that will transform how we live, work, and think, London: John Murray

- Minelli Michael, Chambers Michele, Dhiraj Ambiga(2013):Big data, big analytics, New Jersey, NJ: John Wiley \& Sons

- Pavlović Rastko, Dejanović Ratko (2014):“Big Data i poslovna strategija”, InfotegJahorina, Bosna i Hercegovina, 13, 754-758

- Phillips Casey (2014):"How Smartphones Revolutionized Society in Less than a Decade", GovTech, November $20^{\text {th }}$

- $\quad$ Ross Jeanne, Beath Cynthia, Quaadgras Anne (2013):"You May Not Need Big Data After All", Harvard business review, 10/2013

- Song Il-Yeol, Zhu Yongjun (2017):“Big Data and Data Science: Opportunities and Challenges of iSchools", Journal of Data and Information Science, 3/2017, 1-18

- Tomić Nenad, Todorović Violeta (2016) Possibilities for Application of Electronic Payment Systems in Retail, in: Sinteza 2016 - International Scientific Conference on ICT and E-Business Related Research, Belgrade, Singidunum University, Serbia p. 461

- Tomić Nenad, Todorović Violeta (2018):"Challenges of transition to cashless society" 313-320, in: Babić Verica (ed.) Contemporary issues in Economics, business and management - EBM 2018 [proceedings of the international scientific conference],Kragujevac: Faculty of Economics,

- Tsumoto Shusaku, Hirano Shoji, Iwata Haruko (2013). Mining nursing care plan from data extracted from hospital information system. Paper presented at the 2013 IEEE/ACM International Conference on Advances in Social Networks Analysis and Mining, Niagara Falls, ON, Canada, Big Data in Health Care: Applications and Challenges

- Waldherr Annie, Maier Daniel, Miltner Peter, Günther Enrico (2016) "Big Data, Big Noise: The Challenge of Finding Issue Networks on the Web”, Social Science Computer Review, 4/2016, 427-443

\section{Internet pages}

- https://ecommercenews.eu/key-figures-mobile-commerce-europe-revealed/ (retrieved February $2^{\text {nd }} 2019$ )

- https://press.trendforce.com/press/20160201-2298.html (retrieved February $2^{\text {nd }} 2019$ )

- http://www.paymenteye.com/2016/01/20/big-data-and-mobile-payments-thegame-changer (retrieved February 2nd 2019) 
DOI: 10.5937/MegRev2003115T Pregledni naučni članak

\title{
UTICAJ KONCEPTA BIG DATA NA BUDUĆE TENDENCIJE ELEKTRONSKIH PLAĆANJA
}

\begin{abstract}
Abstrakt: Novi talas transformacije informaciono-komunikacionih tehnologija oslanja se na koncepte interneta stvari, Big Data i mašinsko učenje. Ovi koncepti će omogućiti povezivanje $i$ samostalnu komunikaciju velikog broja uređaja, obradu podataka koji nastaju kao posledica ovih procesa $i$ učenje na osnovu prerađenih informacija. Platni promet je delatnost na koju će dolazeće promene imati veliki uticaj. Veliki broj transakcija stvara informacionu osnovu, čijom analizom se mogu dobiti precizni inputi za donošenje poslovnih odluka. Predmet istraživanja je uticaj upravljanja velikom masom transakcionih podataka na ključne stejkholdere u procesu plaćanja. Cilj rada je identifikovanje ključnih prednosti i opasnosti koje će koncept Big Data doneti platnoj industriji. Generalni zaključak je da primena Big Data alata može olakšati pravovremenu distribuciju platnih usluga i povećati bezbednost transakcija, ali je cena u vidu gubitka privatnosti izuzetno visoka.
\end{abstract}

Ključne reči: Big Data, elektronska plaćanja, privatnost, zloupotreba podataka, mobilni digitalni novčanici; 